\title{
norden
}

Hållbar utveckling i praktiken

Exempel från Norden
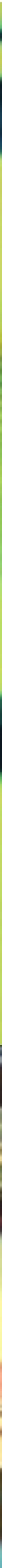


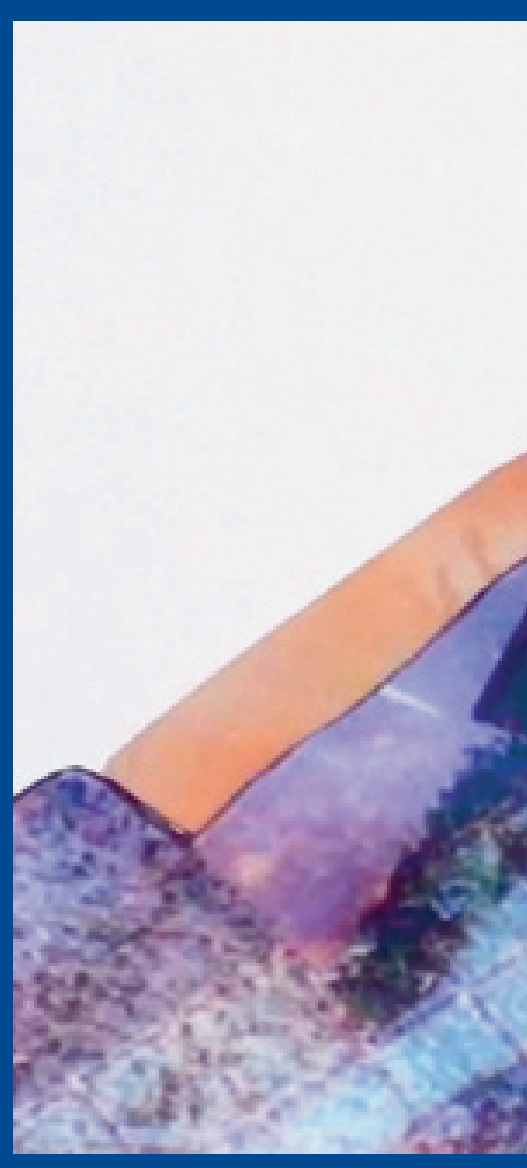




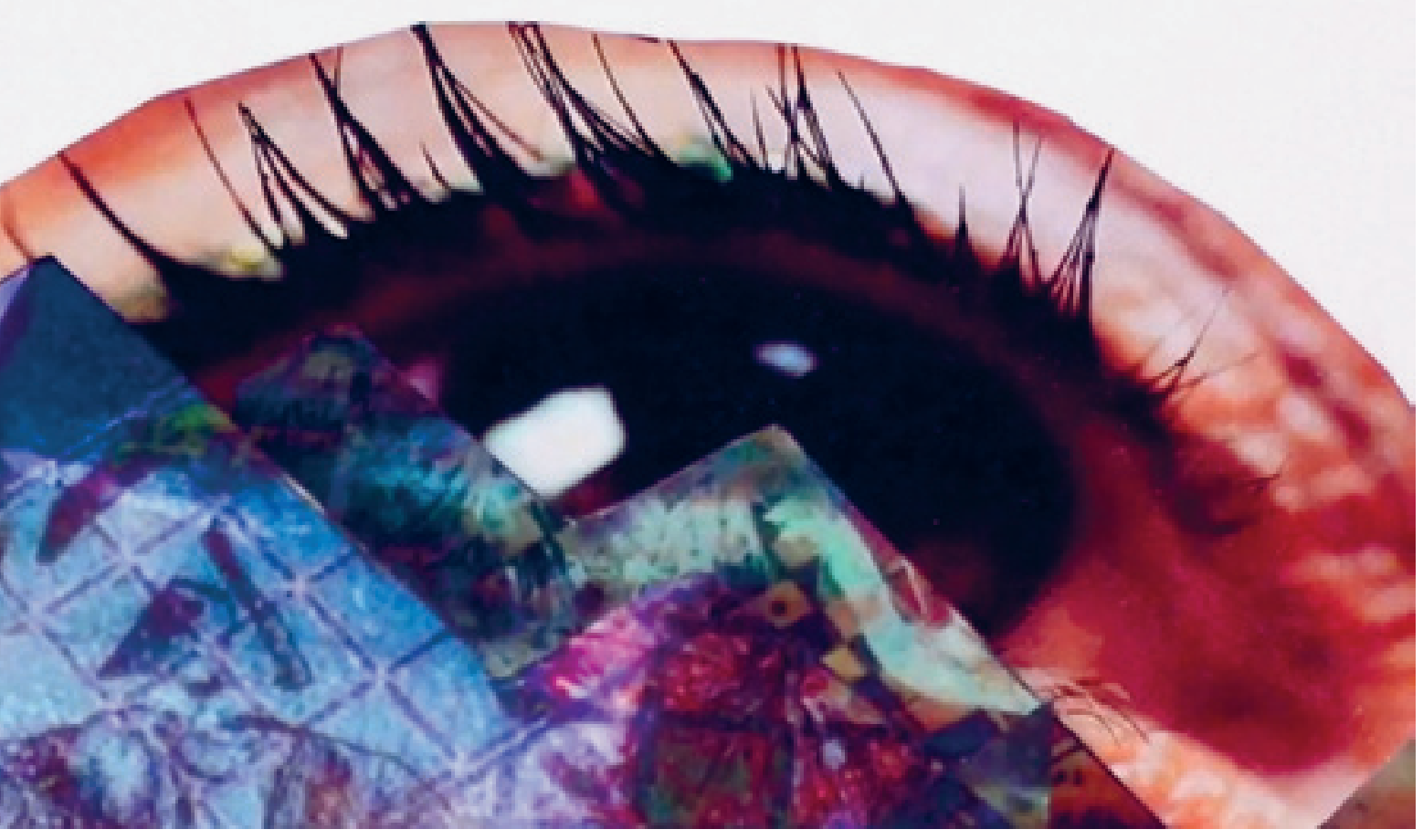




\section{Hållbar utveckling i praktiken}

Exempel från Norden

ISBN: 978-92-893-2360-4

http://dx.doi.org/10.6027/ANP2012-732

ANP 2012:732

(C) Nordiska ministerrådet, Köpenhamn 2012

Layout: Erling Lynder / Nordiska ministerrådet Omslagsfoto: House of Futures och Beate Nøsterud Foto: House of Futures, Beate Nøsterud och Nordbild Tryck: Rosendahls Schultz-Grafisk, Albertslund Upplaga: 1000

Printed in Denmark

\section{Det nordiska samarbetet}

Det nordiska samarbetet är ett av världens mest omfattande regionala samarbeten. Det omfattar Danmark, Finland, Island, Norge och Sverige samt Färöarna, Grönland och Åland.

Det nordiska samarbetet är politiskt, ekonomiskt och kulturellt förankrat och är en viktig partner i europeiskt och internationellt samarbete. Den nordiska gemenskapen arbetar för ett starkt Norden i ett starkt Europa.

Det nordiska samarbetet vill stärka nordiska och regionala intressen och värderingar i en global omvärld. Gemensamma värderingar länderna emellan bidrar till att stärka Nordens ställning som en av världens mest innovativa och konkurrenskraftiga regioner.

\section{Nordiska ministerrådet}

Ved Stranden 18

DK-1061 København K

Telefon (+45) 33960200

www.norden.org 


\section{Hållbar utveckling i praktiken}

\section{Exempel från Norden}

7 Förord

8 Hållbar utveckling är de nordiska ländernas gemensamma prioritering

11 Samnordiska ansträngningar för att möta klimatutmaningen

19 På väg mot mer hållbar konsumtion och produktion

27 Välfärd och hållbar utveckling går hand $\mathrm{i}$ hand

30 En hållbar utveckling kräver kunskap och deltagande 


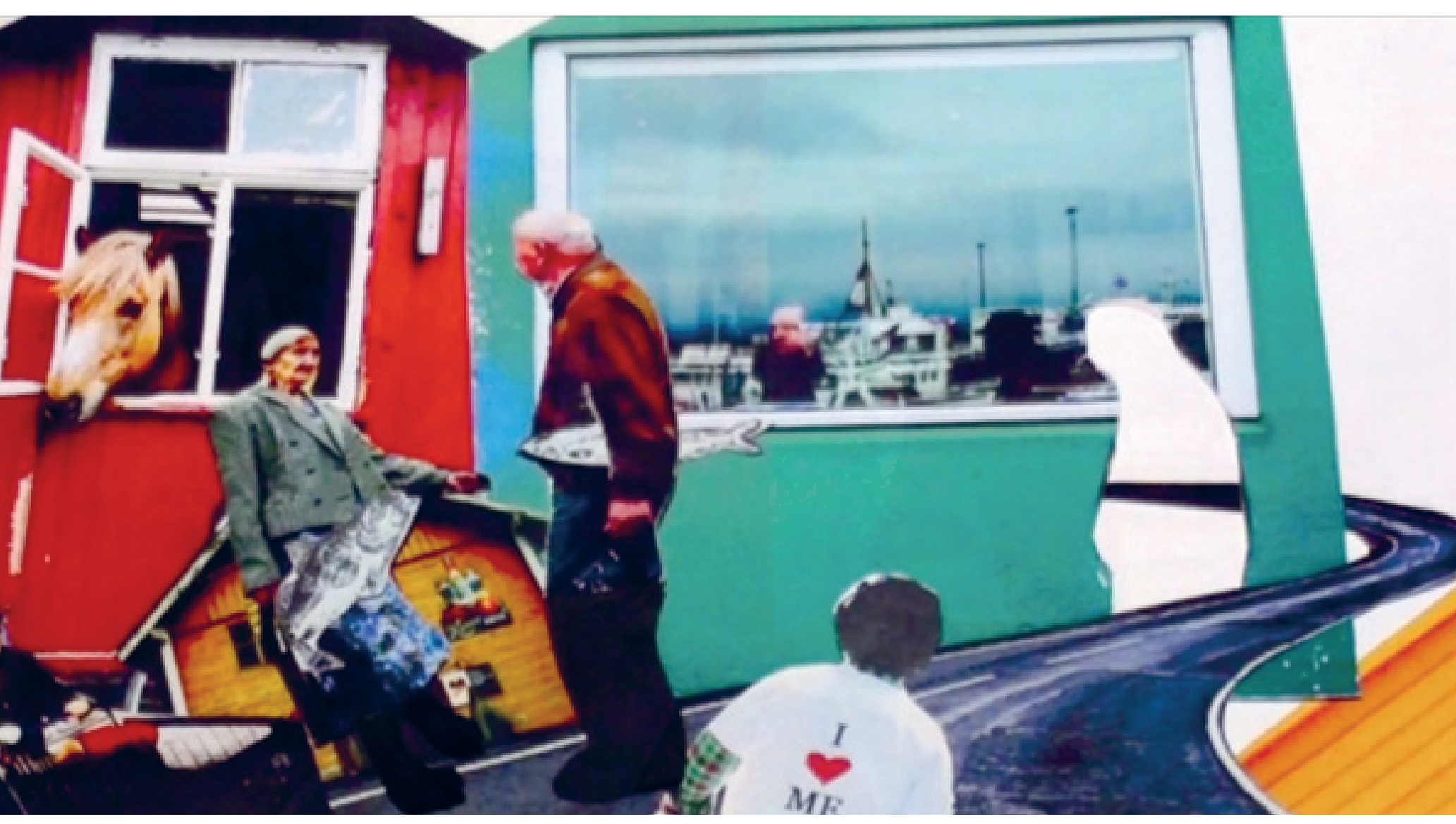




\section{Förord}

"En hållbar utveckling tillfredsställer dagens behov utan att äventyra kommande generationers möjligheter att tillfredsställa sina behov."

Det var så, kort och gott, som den så kallade Brundtlandkommissionen definierade hållbar utveckling i sin rapport "Vår gemensamma framtid" 1987. Med facit i hand kan detta ses som en väckarklocka i bredare mening; frågan om hållbarheten klev konsekvent fram på den politiska dagordningen samtidigt som människornas medvetande om och krav på ett mer hållbart samhällsbygge ökade. Den här definitionen från Brundtlandkommissionen är fortfarande utgångspunkten för arbetet med hållbar utveckling i de nordiska länderna, samtidigt som det breda internationella engagemanget och samarbetet fortsätter och idag kan ses som kanske viktigare än någonsin.

Hållbar utveckling är ett holistiskt begrepp som bygger på insikten att frågorna kring miljöskydd, ekonomiskt välstånd och människors välbefinnande är nära och ofrånkomligt förknippade med varandra. Hållbarhet kräver att samhällsutvecklingen och politiken drivs ur en dynamisk helhetsuppfattning; det som jag gör i dag påverkar det som du kan göra i morgon, och det som du vill göra i morgon har konsekvenser för det som någon annan kan göra i övermorgon. Allt hänger ihop.

Norden placeras i regel i täten i de internationella jämförelserna som mäter olika aspekter av miljöns, människornas och samhällenas välstånd. Vi har under de senaste årtiondena lyckats bevisa att ekonomiskt välstånd och hög välfärdsstandard kan kombineras med en hållbar resursanvändning och miljövård. En gedigen styrka är att den öppna nordiska samhällsstrukturen skapar en stark grund för att diskutera, lyssna och lära, alla förutsättningar för en hållbar utveckling. I övrigt grundar sig den nordiska framgången bland annat på målmedvetna satsningar på ett högklassigt utbildningssystem och insatser på forsknings- och utvecklingsområdet, god förvaltning och fungerande servicesystem, ansvarsfulla och innovativa företag och ett fungerande medborgarsamhälle. Och det hjälper ju också med en stark tradition av samarbete.

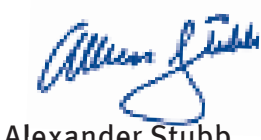

Nordisk samarbetsminister Finland
Samtidigt bör man se framåt med ödmjukhet; vi måste konstant fortsätta att sträva efter mera hållbara samhällen, och vi kan och skall bli ännu bättre på hållbara lösningar. Det krävs innovativt tänkande, ett fortsatt lokalt, regionalt och globalt engagemang, ett ökat utbyte av erfarenheter och kunskaper samt klara signaler från beslutsfattarna. Färgen på framtidens framgångar är grön, inte minst vad gäller miljön, men även med tanke på en sund och konkurrenskraftig ekonomi som i sin tur skapar basen för socialt välbefinnande.

Det nordiska hållbarhetssamarbetet är förankrat i ett globalt perspektiv. Globala frågor är också lokala frågor, och vice versa. Med den här broschyren vill vi dela med oss av nordiska erfarenheter av och exempel på arbetet med hållbar utveckling. Vår förhoppning är att detta ska inspirera till ett fortsatt och ökat regionalt samarbete för hållbar utveckling både i Norden och mellan andra regioner världen över.

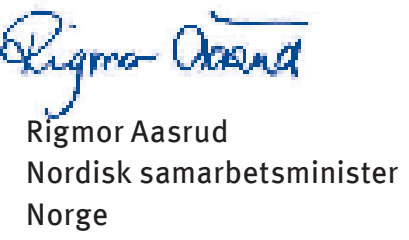




\section{I}

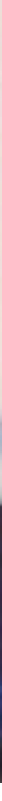




\section{Hållbar utveckling är de nordiska ländernas gemensamma prioritering}

De nordiska länderna står idag inför ett antal gemensamma utmaningar. Globalisering, utvecklingen av informationssamhället, åldrande befolkningar samt ohållbara konsumtions- och produktionsmönster med bland annat klimatförändringar som följd ställer krav på gemensamma insatser för att trygga ett säkert, hälsosamt och värdigt liv för nuvarande och kommande generationer. För att på bästa sätt möta dessa utmaningar och för att kunna dra nytta av de möjligheter som de innebär arbetar de nordiska länderna tätt tillsammans för att skapa förutsättningar för en hållbar utveckling i Norden.

Samarbetet organiseras inom Nordiska ministerrådet, de nordiska regeringarnas officiella samarbetsorgan. Nordiska ministerrådet har en gemensam hållbarhetsstrategi, varav den första lanserades förmodligen som världens första regionala strategi år 2001.

Det nordiska hållbarhetssamarbetet ska komplettera de nationella insatserna och fokusera på områden där vi genom samarbete kan skapa nordiskt nytta och mervärde. Samarbetet ska bidra till ökad kompetens och effektivisera resursanvänd- ningen i den nordiska regionen. Det tvärsektoriella arbetet är centralt för att vi ska lyckas i våra ansträngningar, och vi ska alltid sträva efter att identifiera lösningar som ger goda resultat för alla inblandade.

Under de senaste åren har det nordiska arbetet om hållbar utveckling fokuserat på klimat och förnybar energi, hållbar konsumtion och produktion, välfärdsfrågor samt utbildning och forskning.

www.norden.org/hu
Ett viktigt redskap i arbetet med hållbarhetsstrategin är de nordiska hållbarhetsindikatorerna. Indikatorerna används för att följa utvecklingen i de nordiska länderna samt för att jämföra utvecklingen mellan de nordiska länderna och i ett internationellt sammanhang. Några av indikatorerna presenteras i denna broschyr och fler finns på Nordiska ministerrådets webbplats.

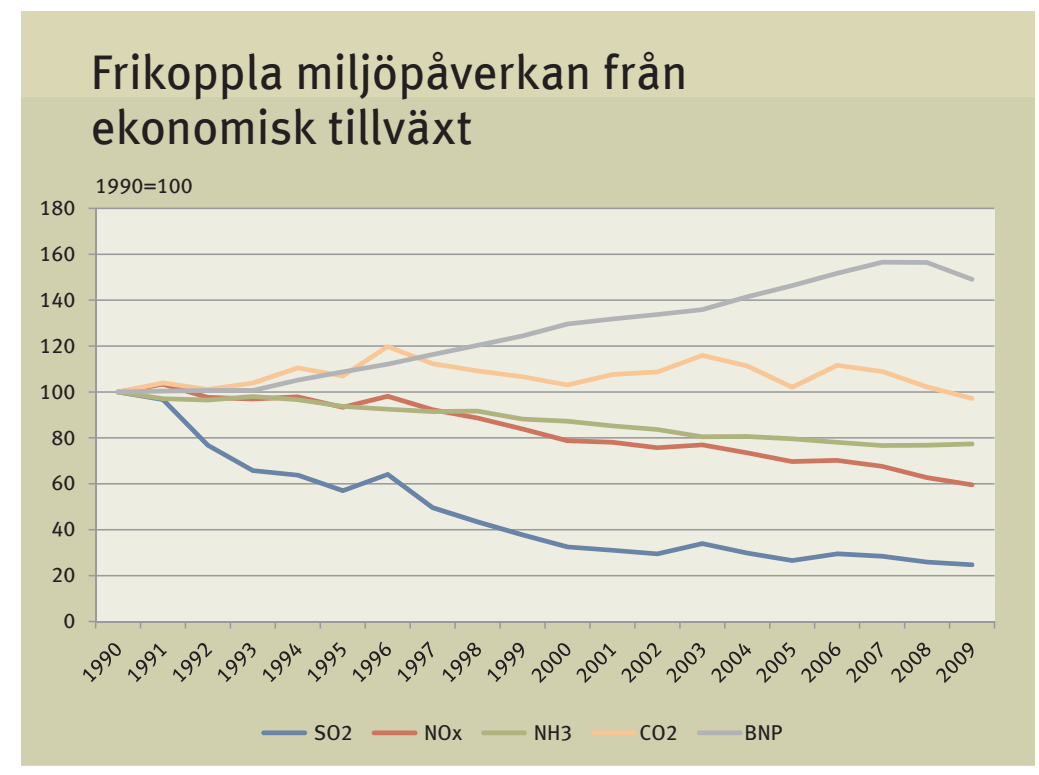




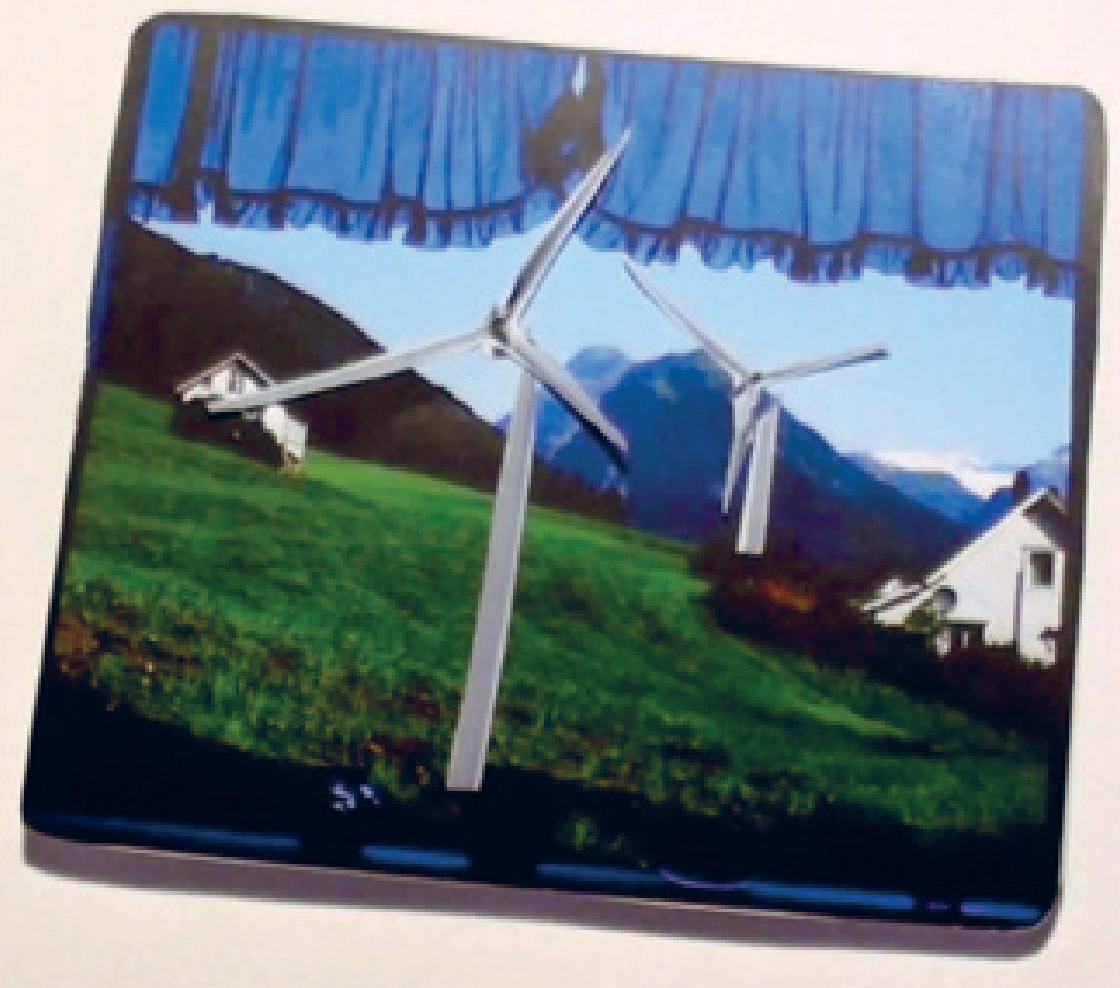




\section{Samnordiska ansträngningar för att möta klimatutmaningen}

De nordiska länderna ska genom ett hållbart nyttjande av naturresurserna svara på klimatförändringens utmaningar samt sörja för regionens biologiska mångfald och öka dess välfärd. För att minska sina bidrag till den globala temperaturökningen har de nordiska länderna som mål att kraftigt minska sina utsläpp, nationellt och inom ramen för FN och EU samt effektivisera energianvändningen. Norden, såväl myndigheter och befolkning som näringsliv, ska förbereda sig på att leva med den klimatförändring som inte kan undgås.

\section{Nordisk kompetens och genomslagskraft i klimat- frågor}

Den nordiska arbetsgruppen för globala klimatförhandlingar (NOAK) grundades år 2007. NOAKs överordnade mål är att bidra till antagandet av ett globalt klimatavtal med bindande och ambitiösa mål. Gruppens verksamhet går ut på att ta fram studier och underlag om viktiga förhandlingsfrågor framför allt för de nordiska ministrarnas och klimatförhandlarnas behov. NOAK arrangerar också internationella möten och workshoppar tillsammans med andra förhandlingsparter och sprider information om aktuella globala klimatfrågor i Norden.
FN:s klimatkonferens i Cancún 2010 beslutade att hålla den globala uppvärmningen under två grader, något som kräver omfattande åtgärder från alla länders sida. De utvecklade länderna har lovat att stödja utvecklingsländerna i detta enorma uppdrag genom kapacitetsuppbyggnad, teknologiöverföring och finansiering.

Som ett bidrag till klimatkampen har de nordiska länderna beslutat att finansiera ett nytt program för utsläppsreduktion, Nordic Partnership Initiative on Up-scaled Mitigation Action, NPI. Programmet ska hjälpa Peru och Vietnam att minska sina utsläpp inom de kraftigt förorenande sektorerna avfallshantering och cementtillverkning.

NPI visar hur internationell klimatfinansiering bättre kan sammanjämkas med intensivare sektorbaserade insatser i utvecklingsländer. Målet är att bygga upp värdlandets kapacitet att evaluera, strukturera och implementera nationellt anpassade åtgärder, så kallade NAMAs (Nationally Appropriate Mitigation Actions), som utnyttjar internationell finansiering och eventuella nya marknadsmekanismer. Tanken är också att det nordiska programmet kan fungera som en framtida modell för åtgärder även inom andra sektorer.

www.norden.org/npi

\section{Arktis påverkas av klimat- förändringarna}

En stor del av de nordiska land- och havsområdena ligger i den arktiska regionen. Nordiska ministerrådet är därför starkt engagerat i frågor som rör detta unika och kärva men också sårbara område.

Klimatförändringarna har inneburit omfattande förändringar i Arktis. För att förstå utvecklingen och för att planera för en hållbar framtid i och utanför regionen är det viktigt att ha goda kunskaper om de processer, förutsättningar och utmaningar som påverkar området. I Nordiska ministerrådets projekt Megatrends kartläggs därför ett urval av de processer som påverkar möjligheterna för en hållbar utveckling i Arktis. Projektet identifierar nio olika utvecklingstendenser som är så kraftfulla att de kan förändra våra samhällen i grunden - från lokal till global nivå. Dessa megatrender har potential att förändra vårt sätt att leva och tänka, och måste därför tas med i 
beräkningen när vi planerar för en hållbar framtid.

Flertalet megatrender som utgör en påverkansfaktor för de arktiska områdena berörs i Nordiska ministerrådets diversifierade samarbete. En uppföljning av rapporten i form av konkreta initiativ förväntas kunna bidra till strävan efter en hållbar utveckling i Arktis. Insatserna kan exempelvis komma att beröra miljö- och energifrågor, välfärd och hälsa för arktiska befolkningar och demografiska utmaningar i arktiska samhällen.

www.norden.org/

sv/publikationer/

publikationer/2011-711

\section{Hållbar utveckling ur ett jämställdhetsperspektiv}

Debatten om klimatförändringarna tenderar framförallt att fokusera på de teknologiska och ekonomiska sidorna av klimatförändringarna och mindre på sociala och mänskliga aspekter.

Men kvinnor och män påverkar och påverkas av klimatet och klimatförändringarna på olika sätt. Transport, kommunikation och avfallshantering är exempel på områden där man kan se skillnader mellan mäns och kvinnors vanor och förhållningssätt. Nordiska ministerrådets projekt Jämställdhet och klimatförändring ska skapa synlighet, förståelse och kunskap om klimatförändringarna och hållbar utveckling ur ett jämställdhetsperspektiv.

Tanken är att projektet ska skapa dialog kring hållbar utveckling, klimat och jämställdhet på lokal, regional, nordisk och global nivå. Inom ramen för projektet arrang- eras bland annat seminarier och sidoevenemang där myndigheter, politiker, forskare och NGO:er kan mötas och diskutera problem och lösningar. Projektet ska också presentera lokala lösningar för hur kvinnor och män kan bidra till en hållbar utveckling genom att ändra på sina beteendemönster.

En ny nordisk elektronisk kunskapsplattform, Equal Climate - Kön och klimatförändring ur ett nordiskt perspektiv, fokuserar på sambandet mellan kön, konsumtionsmönster, koldioxidutsläpp, kunskap och beslutsfattande. Plattformen samlar information om temat, förmedlar praktiska exempel, berättar om de nordiska ländernas samt Färöarnas, Grönlands och Ålands aktiviteter och följer upp specifika rekommendationer från Nordic Summit-deklarationen 2009.

www.equalclimate.org

www.norden.org/jam 


\section{Kommunalt kunskapsutbyte - en väg till klimatvänliga lösningar}

Kommunerna har en nyckelposition i de nordiska ländernas arbete för att hantera klimatförändringarna. Det ansvar som denna nyckelposition medför bär de nordiska kommunerna till fullo, visar en analys gjord inom ramarna för det nordiska projektet Nordic Climate Cooperation on the Municipality Level (NOBILITI). Mer än hälften av kommunerna har exempelvis genomfört omfattande åtgärder för att minska sin energiförbrukning, vidtagit åtgärder för att hantera ökade regnmängder och/eller justerat stadsplaneringen i en mer hållbar riktning.
Men NOBILITI:s analys visar också en outnyttjad potential i att kommunerna i högre utsträckning kan lära av varandra om de vill. De klimatinitiativ som genomförs i kommuner runt om i Norden har nämligen många likheter, men trots detta drar man inte nödvändigtvis nytta av de lärdomar som andra kommuner i Norden kan bidra med. Detta innebär att många kommuner ofta "börjar om från början" i sina olika klimatansträngningar - istället för att lära sig av och bygga vidare på andra kommuners praktiska erfarenheter och lösningar. Här finns alltså utrymme för att spara resurser genom att dela erfarenheter och kunskaper över kommungränserna.
För att förenkla och uppmuntra till ett ökat utbyte av idéer och erfarenheter mellan de nordiska kommunerna har NOBILITI arrangerat en konferens för kommunerna och mot den bakgrunden kommer en katalog att sammanställas över utvalda lyckade kommunala klimatprojekt och de faktorer som spelar störst roll i ett lyckat genomförande av ett givet kommunalt klimatprojekt - vare det handlar om anpassning eller reduktionsinsatser/energioptimering. Katalogen ska fungera som ett idé- och adresskatalog över nordiskt kommunalt klimatarbete för ett ökat samarbete över nations- och kommungränserna.

www.nobiliti.org 


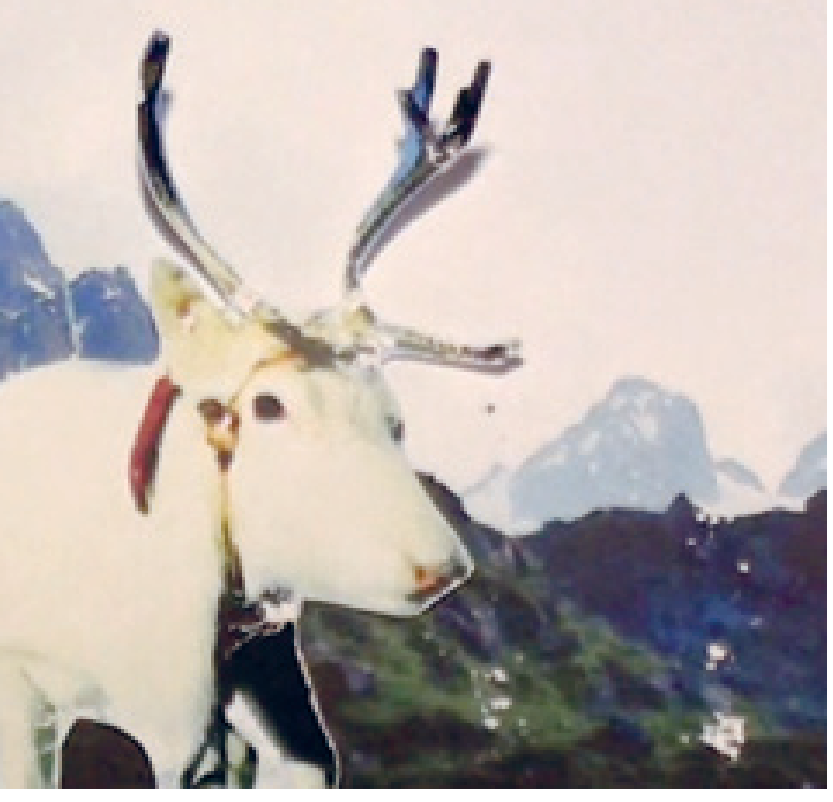

\section{Innovativa energikommuner} Projektet Nordisk energikommun 2011 satte fokus på hållbar energi, grön tillväxt och det energirelaterade klimatarbetet i Norden. Projektet hade som mål att ge ett särskilt erkännande till de nordiska kommuner som gör en extraordinär insats för att genomföra banbrytande energiprojekt. Alla nordiska kommuner har bjudits in till att delta i tävlingen.

44 nordiska kommuner skickade in en ansökan och lyfte fram och beskrev ett särskilt energiprojekt som de hade genomfört. 14 av dessa kommuner nominerades till att få ett erkännande som nordisk energikommun.

I samband med de nordiska statsministrarnas globaliseringforum $i$ oktober 2011 korades den danska kommunen Albertslund till Nordisk energikommun 2011, vald av en internationell jury. Samtidigt fick både den norska kommunen Drammen och Lidköpings kommun från Sverige ett särskilt erkännande för sina projekt.

www.nordiskenergikommune.org/ 


\section{Förnybar energi - en viktig prioritering}

De nordiska länderna får redan idag en stor del av sin primärenergi från förnybara källor, men det finns potential för att öka andelen betydligt. Utvecklingen av förnybara energikällor är därför en viktig del av klimatpolitiken i alla de nordiska länderna och många privata företag i Norden lägger stora resurser på området. För att stödja utvecklingen av förnybar energi utnyttjar länderna bland annat ekonomiska styrmedel, till exempel gynnas förnybara energikällor skattemässigt. Länderna ger också riktat stöd till forskningsoch utvecklingsprojekt.

Arbetsgruppen för förnybar energi har till uppgift att främja användningen av förnybar energi i Norden genom gemensamma insatser för att belysa hur förutsättningar och konkurrensvillkor (ramvillkor) för förnybar energi kan förbättras. Detta görs genom utbyte av information och erfarenheter samt genom initiering av gemensamma projekt. Sådana projekt kan omfatta kartläggning av möjligheter för utökat samarbete inom ett givet område.

Ett exempel är arbetsgruppens studie om hur de nordiska länderna kan implementera samarbetsmekanismerna som hör till
EU:s direktiv om förnybar energi. Detta projekt sker i dialog mellan olika intressenter, både inom och utanför Norden, och har rönt stort intresse. I en annan studie tittar gruppen på möjligheter för ökat nordiskt samarbete inom fast biomassa för energiändamål.

\section{Förnybara energikällors andel av bruttoenergiförbrukningen}

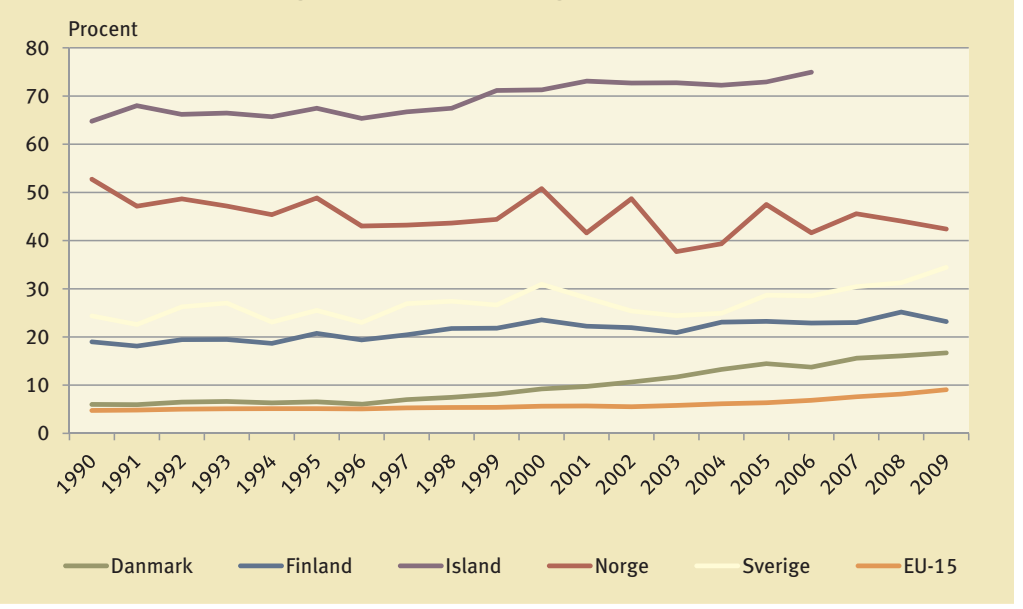




\section{Projektet NordVind under- söker förutsättningarna för mer vindkraft i Norden}

Projektet NordVind undersöker vilka förutsättningar det finns för utbyggnad av vindkraften i Danmark, Finland och Sverige. Projektet har fokus på hur de offentliga myndigheterna i länderna hanterar utbyggnad av vindkraft. I projektet undersöks bland annat vilka politiska mål som har formulerats i förhållande till vindkraftsutbyggnad och hur planeringen ser ut.

Man ser också på myndighetshandläggningen och de ekonomiska villkoren liksom på de miljömässiga förutsättningarna samt forskning och utveckling. Tanken är att dessa faktorer tillsammans ska ge en bild av de möjligheter och hinder som föreligger för att bygga ut vindkraften i de tre länderna.

Inom ramarna för NordVind har det också inrättats en arbetsgrupp med representanter från olika offentliga myndigheter i Norden som har till uppgift att främja en förbättrad samordning av de offentliga planläggningsprocesserna på vindkraftsområdet.

\section{www.NordVind.org}

\section{Nordic Built}

Norden är leverantör av viktiga komponenter till energieffektiva byggnader, såsom isoleringsmaterial, pumpar, fönster och ventilationssystem. De nordiska länderna har även en högt ansedd arkitektur och design samt strikta regleringar drivna av höga politiska ambitioner. Trots detta har den nordiska byggbranschen inte till fullo utnyttjat sina fördelar och positionerat sig som en ledande region för utveckling och export av hållbara och energieffektiva koncept.

Målet med Nordic Built är att stimulera nordiska konkurrenskraftiga koncept för ett hållbart byggande - med särskilt fokus på det befintliga byggbeståndet. Nordic Built genomförs i tre moduler, av vilka den första handlar om att definiera och skapa en gemensam identitet och en gemensam väg framåt. Den andra modulen är utformad som en tävling, där innovatörer från och utanför byggsektorn ska tävla om att energirenovera fem konkreta byggnader i Norden. Den tredje modulen kommer att bygga på befintliga nationella insatser för att skapa skalbara, konkurrenskraftiga lösningar för uppgradering av det befintliga byggbeståndet.

Tillsammans ska de tre modulerna ge fart och acceleration till omfattande nordiska ansträngningar för att lösa den stora utmaning som det befintliga byggbeståndet utgör.

www.nordicinnovation.org/ da/projekter/nordic-climatefriendly-buildings/ 


\section{Grönland satsar på grön energi}

Grönland har sedan början av 1990-talet systematiskt satsat på en ökad användning av förnybar energi - både för att trygga en jämn energiförsörjning och för att minska användningen av olja. Vattenkraften är den förnybara energikälla som har störst utvecklingspotential i landet.Idag finns fyra vattenkraftverk i drift i Grönland. Ännu ett verk är under uppbyggnad i Ilulissat, Grönlands tredje största stad. Vattenkraftverket förväntas tas i drift i början av 2013 och kommer då att försörja llulissats invånare (5 000 personer) med förnybar energi.

Omställningen till förnybar energi innebär miljardstora investeringar för Grönland. I ett land med bara 56000 invånare betyder detta att satsningen på hållbar energi har mycket hög politisk prioritet.

När vattenkraftverket i llulissat invigs kommer 70 procent av den statliga energiproduktionen att utgöras av energi från förnybara källor. Det motsvarar drygt 40 procent av den totala energiproduktionen, det vill säga både offentlig och privat, på Grönland.

Grönlands nationella energibolag Nukissiorfiit - som står för driften av de statliga vattenkraftverken - arbetar också för att utveckla andra metoder som kan reducera användningen av fossila bränslen. Bolaget har bland annat investerat i en vätgas- och bränslecellsanläggning som ska öka kunskapen om vätgas som energibärare. Vätgas kan användas för att ta vara på de grönländska vattenkraftverkens överskottskapacitet.

Två andra aktuella initiativ är ett testprojekt för elbilar i huvudstaden Nuuk och en analys av användningen av så kallad Pumped Storage (pumpkraftverk) på Grönland. Dessutom arbetar man för att påverka konsumenternas beteende genom olika kampanjer. 


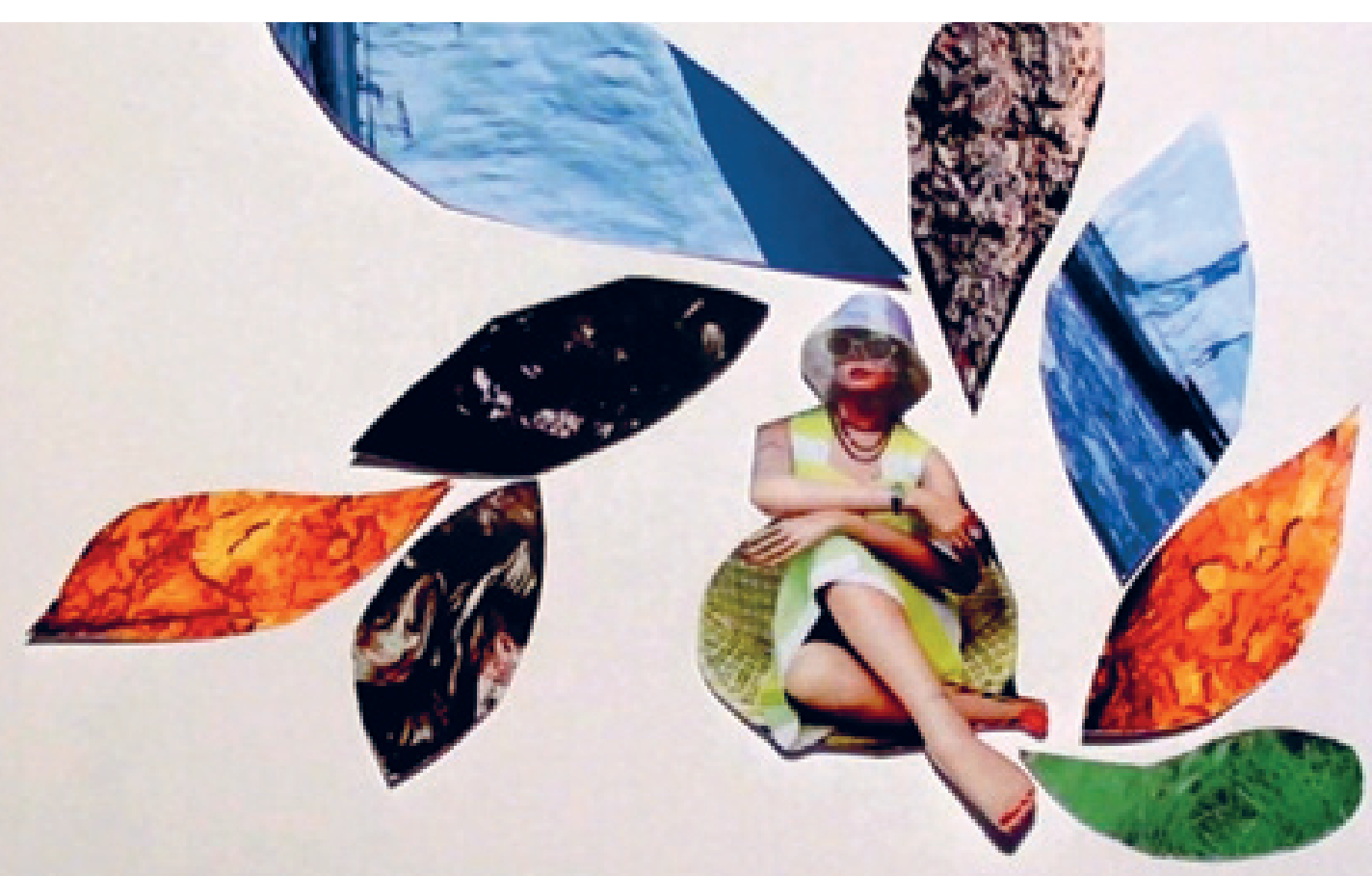




\section{På väg mot mer hållbar konsumtion och produktion}

Ekonomisk tillväxt skapar förutsättningar för ökad konsumtion, högre materiell välfärd, högre boendestandard och förbättrad hälsa. Men ekonomisk tillväxt innebär också nya sociala och miljömässiga utmaningar. När tillväxten leder till att ekosystemen överutnyttjas och förorenas får den kraftfulla negativa konsekvenser för både miljön och människors välmående. Många av de miljö- och hälsoproblem som vi ser idag hör ihop med en ohållbar konsumtion och produktion av produkter och tjänster, vilket påverkar ekosystemen negativt.

Väl fungerande ekosystem är ett måste för att vi ska ha tillgång till ekosystemtjänster som rent vatten, ren mat och andra biologiska råvaror. För att vi i framtiden ska kunna må bra och leva väl måste vi därför värna om våra ekosystem. Nordiska ministerrådet arbetar aktivt för att skapa mer hållbara konsumtions- och produktionsmönster i de nordiska samhällena.

\author{
Ett samhällsekonomiskt \\ perspektiv på ekosystemen \\ Under senare år har det fästs \\ allt större uppmärksamhet vid \\ begreppet ekosystemtjänster, det \\ vill säga de livsnödvändiga tjäns- \\ ter som våra ekosystem erbjuder \\ i form av exempelvis rent vatten, \\ ren luft och en god miljö. Ekosys- \\ temtjänsterna är också nödvän- \\ diga för jordbruket, skogsbruket \\ och andra areella näringar.
}

Sunda och välfungerande ekosystem är en förutsättning för en god ekonomisk utveckling och för att den biologiska mångfalden ska kunna bevaras. Nordiska ministerrådet arbetar därför aktivt för att ta fram verktyg som gör det möjligt för de nordiska länderna att inkludera hänsyn till ekosystemen i sitt ekonomiska beslutsfattande.

\author{
Projektet TEEB Nordic - The State \\ and Economics of the Key Ecosys- \\ tem Services in the Nordic Countries \\ - kartlägger ekosystemens och den \\ biologiska mångfaldens samhälls- \\ ekonomiska betydelse i de nord- \\ iska länderna. Kartläggningen tar \\ utgångspunkt i FN:s globala TEEB- \\ initiativ med målet att fördjupa den \\ globala kartläggningen med en \\ regionalt mer djupgående analys.
}

TEEB Nordic ska identifiera de mest centrala ekosystemtjänsterna $i$ de nordiska länderna, undersöka vilka tjänster som är viktigast ur samhällssynpunkt och ekonomisk synpunkt samt undersöka hur naturens verkliga (ekonomiska) värde på sikt kan inkluderas i det politiska beslutsfattandet. Förhoppningen är också att projektet ska bana väg för ytterligare regionala och nationella TEEB-initiativ runt om i världen. www.ieep.eu/work-areas/biodiversity/valuing-biodiversityand-ecosystem-services/2011/02/initiating-a-teebassessment-for-the-nordic-countries 


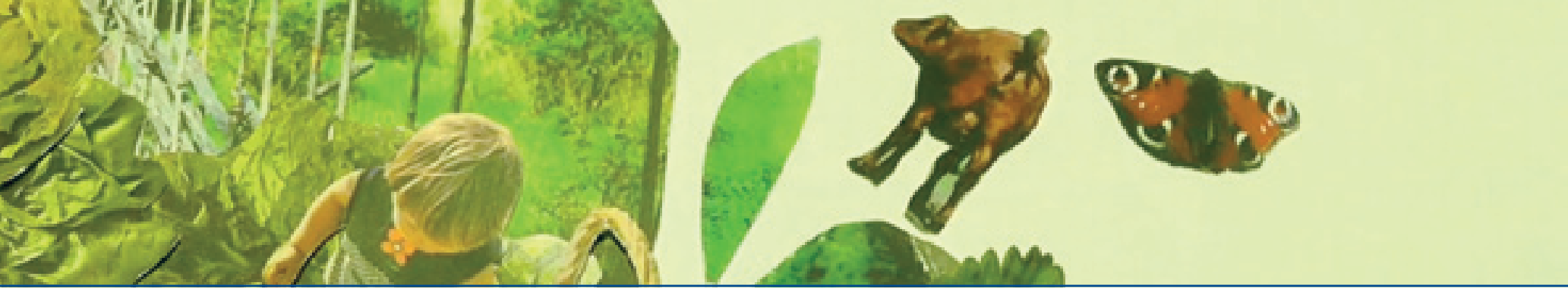

\section{Ekonomiska styrmedel för att skapa nya konsumtions- och produktionsmönster}

Den miljöpolitiska regleringen i de nordiska länderna har på detta område undergått en dramatisk förändring. Norden har här tagit täten $i$ en förnyelseprocess som innebär att den traditionella miljöpolitiska regleringen i form av normer och tillstånd breddats till att $i$ allt högre grad omfatta nya marknadsbaserade instrument, exempelvis miljöskatter. Ett av målen med den ökade användningen av marknadsbaserad styrning är en strävan efter att faktiskt sätta en prislapp på miljöbelastningen.

De nordiska länderna kännetecknas av ett relativt högt skattetryck. Införandet av miljörelaterade skatter har i regel inte ökat skattetrycket eftersom länderna satsat på så kallad skatteväxling, det vill säga att skatter på arbete har ersatts med miljöskatter. I några enskilda fall har man också öronmärkt skatter och avgifter för miljörelaterade ändamål. Miljörelaterade avgifter och utsläppsrätter har också använts med framgång. I synnerhet på klimatpolitikens område spelar den marknadsbaserade styrningen en allt större roll i samtliga nordiska länder.

Den gradvisa omläggningen av miljöpolitiken har gett bra resultat i form av ökad kostnadseffektivitet kombinerad med minskad miljöbelastning på många områden. De nordiska erfarenheterna tyder på att en ambitiös miljöpolitik kan kombineras med en sund ekonomisk utveckling. 


\section{Miljömärkning - framgångssagan Svanen}

Den stora arsenalen av miljöpolitiska verktyg i Norden består inte enbart av ekonomiska styrmedel. Norden har varit tidigt ute även när det handlar om miljömärkning och miljöstyrning i näringslivet. Konsumtionsbaserade miljöfrågor har fått en allt större uppmärksamhet och samarbetet mellan olika aktörer ökar inom detta område.

Den officiella nordiska miljömärkningen Svanen som etablerades år 1989 är en viktig del av det nordiska miljöarbetet och medverkar till att minska den börda som den dagliga konsumtionen lägger på miljön. Svanenmärket granskar varors och tjänsters miljöpåverkan under hela livscykeln från råvara till avfall. Det ställs hårda klimatoch miljökrav men även krav på funktion och kvalitet. Svanen ska bidra till att vägleda de nordiska konsumenterna och inköparna så att de får en verklig möjlighet att handla grönt och därigenom medverka till en minskad miljöbelastning av sin konsumtion. En ökad efterfrågan stimulerar producen-

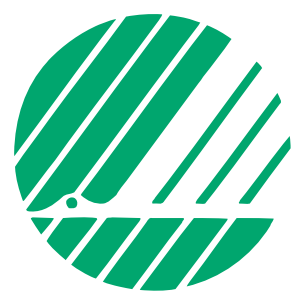

terna till att framställa miljövänliga produkter. Det är meningen att Svanen ska vara ett attraktivt och trovärdigt sätt för företag att använda miljö som konkurrensmedel och ett självklart val för konsumenter med höga krav på miljö och kvalitet. 
Idag är Svanen en välkänd och uppskattad miljömärkning. En nyligen genomförd undersökning visade att 94 procent av befolkningen $\mathrm{i}$ Norden kände till och identifierade Svanen som en miljömärkning. Det har hittills utfärdats över 2000
Svanen-licenser som totalt inkluderar mer än 6000 produkter, och antalet licenser ökar kraftigt hela tiden.

www.nordic-ecolabel.org

\section{Antal licenser på miljömärkta produkter och tjänster}

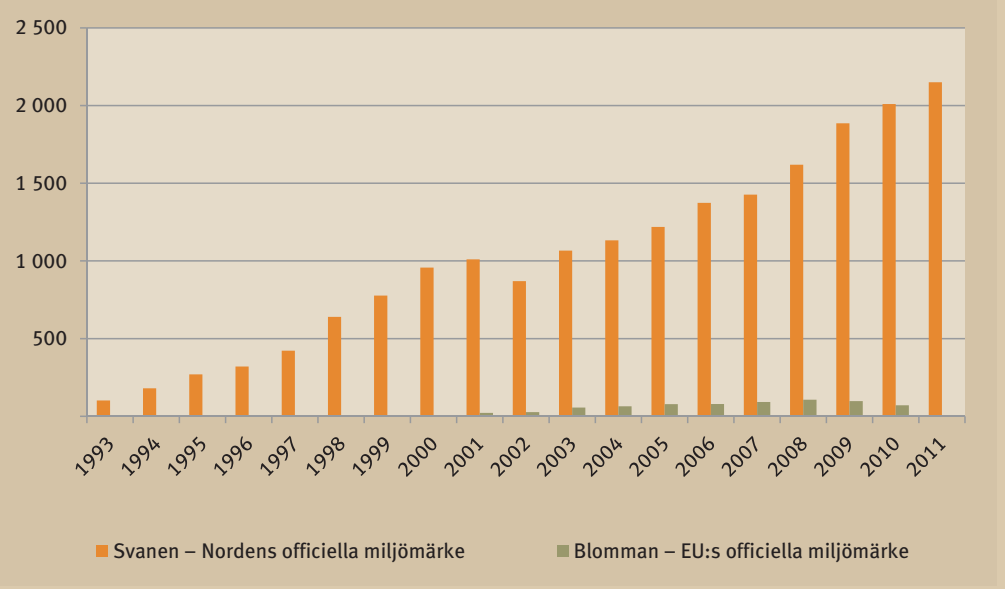

Källa: Ecolabelling Denmark. Tabellen visar antalet licenser som utfärdats av Nordic Ecolabel och antal licenser utfärdade till nordiska producenter av EU Ecolabel. 


\section{Miljömärkning som konkurrensmedel - Svanen växer på Island}

Island har från start tagit del i utvecklingen av Svanen, men miljömärket har trots detta haft en ganska svag marknadsposition på Island. Under de senaste två åren har det isländska miljödepartementet därför satsat stora resurser på Svanen. Resultatet har inte låtit vänta på sig. År 2008 fanns endast tre isländska företag med Svanen-licens. Idag, fyra år senare, har antalet ökat till 19 och ökningen fortsätter i snabb takt.

Samtidigt känner fler och fler islänningar till märket. En gallupundersökning som genomfördes i december 2011 visade att 73 procent av befolkningen känner igen Svanenmärket. Man skulle kunna tro att den senaste tidens ekonomiska problem i Island skulle vara ett hinder för spridningen av miljömärkningen, men det verkar tvärtom vara så att företagen uppfattar Svanen som ett viktigt konkurrensmedel. Tryckeri-, rengörings- och nu senast hotellbranschen har varit föregångare i utveck- lingen. På Island finns nu sju tryckerier, fem rengöringsfirmor och fem hotell eller vandrarhem som är Svanen-certifierade.

Den offentliga sektorn har ett ansvar att fortsätta främja miljömärkt industri och tjänster. I kraft av sin storlek har offentliga inköp möjlighet att påverka marknaden och gynna en miljöriktig produktion av varor och tjänster. Statens inköpscenter har översatt 16 miljökriterier som används av alla offentliga instanser vid upphandling av olika produkter och tjänster. Dessutom får varje institution ett personligt besök av rådgivare som ger inköpspersonalen assistans i implementeringen av miljökriterierna, samlar in information om hur långt institutionen har kommit och erbjuder undervisning för personalen. Dessa besök har fått ett mycket positivt mottagande och visar att den offentliga sektorn är öppen för och angelägen om att ställa om till gröna inköp. 



\section{Virtuella servrar - verklighet i Danmark}

När Köpenhamns kommun skulle upphandla nya servrar tog de hjälp av Statens och Kommunernas Indkøbsservice. Det nya avtalet kommer att minska koldioxidutsläppen och kostnaderna, samtidigt som kvaliteten ökar.

Köpenhamns kommuns 638 servrar har ersatts med 32 stycken nya ihopkopplade servrar. De nya servrarna är större och effektivare vilket gör att den totala serverkapaciteten ökar trots att antalet har minskat tjugofalt.

Avtalet löper på fem år och är en stor ekonomisk investering. Trots det räknar kommunen med att spara pengar i det långa loppet. Servrarna är samlade på en plats, vilket un- derlättar driften. Kylsystemet i serverrummet är optimerat för att kunna kyla olika platser specifikt, vilket minskar energibehovet med cirka 33 procent. Leverantören lovar dessutom att klimatkompensera servrarna. Detta sker genom att 500 träd planteras i Indien, som binder koldioxid motsvarande utsläppen från servrarnas strömanvändning.

Den nya lösningen minskar koldioxidutsläppen med 3550 ton. Det är 75 procent mindre än de gamla servrarna. Dessutom kräver den nya installationen mindre energi och service vilket sparar cirka 1,6 miljoner danska kronor om året. Det är ett mycket bra exempel på hur kvalitet, miljö och ekonomi kan gå hand i hand. 


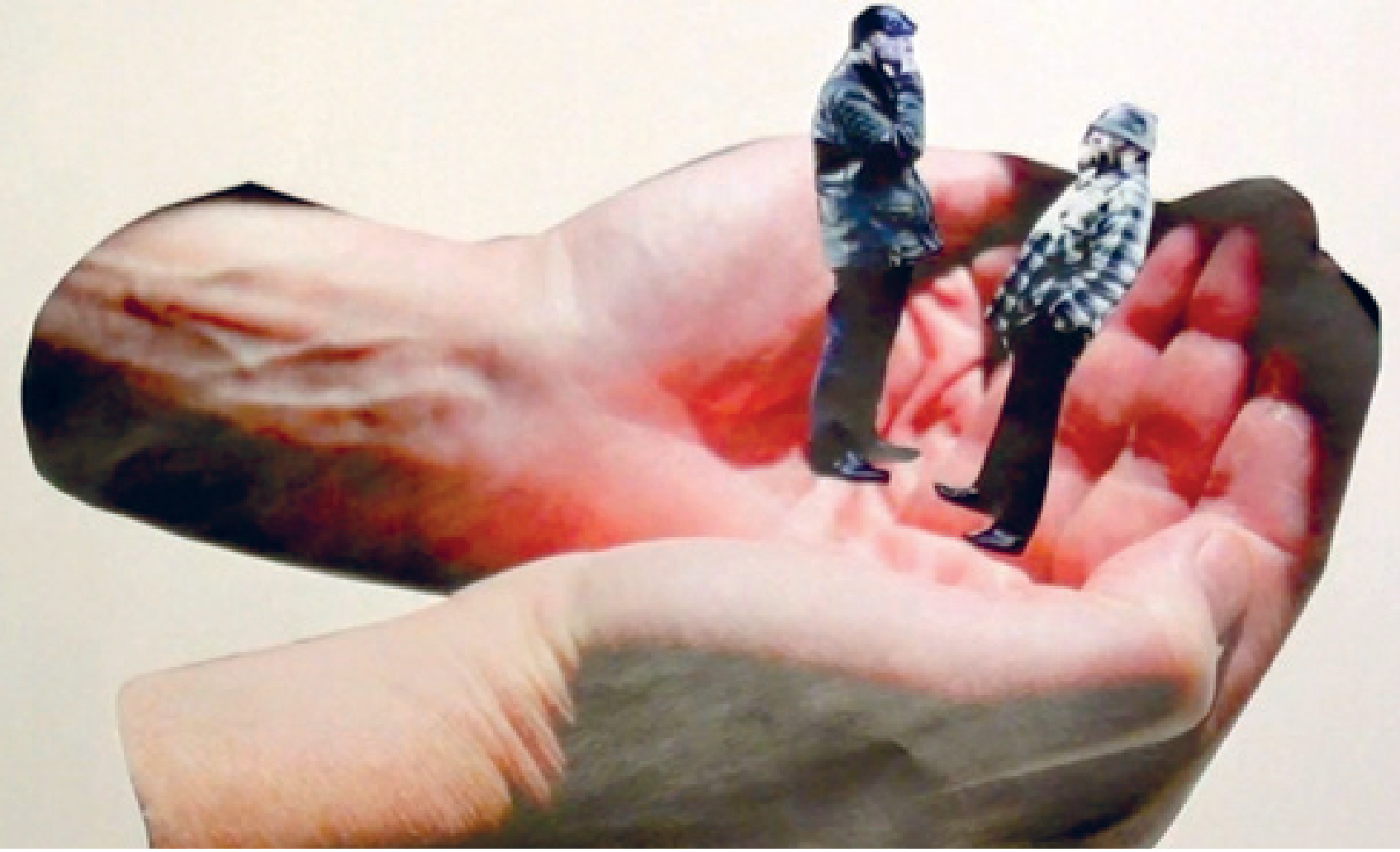




\section{Välfärd och hållbar utveckling går hand i hand}

Även om de nordiska länderna inte löser välfärdsuppgifterna på precis samma sätt finns det så stora likheter mellan länderna att man brukar tala om "den nordiska välfärdsmodellen". Den nordiska välfärdsmodellen bygger på demokrati, jämställdhet, god administration, korruptionsbekämpning, kostnadsfri utbildning, tillgång och rättigheter till hälsovård och sociala tjänster och allmän socialförsäkring, som skapar möjligheter och förutsättningar för att effektivt driva hållbar utveckling. De nordiska länderna har lyckats förena höga inkomstnivåer, en måttfull ekonomisk tillväxt, en stabil ekonomi och socialt välbefinnande.

Det finns också stora likheter mellan länderna när det gäller de utmaningar man kommer att behöva hantera i framtiden. Länderna står alla inför uppgiften att identifiera innovativa lösningar för att möta bland annat demografiska förändringar och globalisering, samt för att säkra en god och jämlik folkhälsa och motverka förekomsten av relativ fattigdom.

De enhetliga nordiska samhällssystemen gör det relativt lätt att snegla på varandra länderna emellan och låta sig inspireras av det bästa i grannländerna. Nordiska ministerrådet genomför fortlöpande initiativ för att stimulera utbyte av erfarenheter, vidareutveckling och samarbete på det välfärdspolitiska området. En viktig dimension i Nordiska ministerrådets arbete på välfärdsområdet är också att stärka dialogen och samarbetet regionalt och internationellt. Detta sker genom att ha kontakt med europeiska och internationella organisationer som Europarådet, WHO och den nordliga dimensionens partnerskap på social- och hälsoområdet.

\section{Omfattande initiativ för bät- tre hälsa och välfärd}

Det nordiska globaliseringsinitiativet för hälsa och välfärd, Norden som konkurrenskraftig och unik välfärdsregion - en god region att investera, arbeta och leva $i$, är ett treårigt nordiskt samarbetsprogram som utarbetats för att bidra till den nordiska välfärdsmodellens hållbarhet och konkurrenskraft.

Initiativet består av sju delprojekt som på olika vis ska stärka Nordens ställning inom den globala hälso- och välfärdssektorn. Initiativet främjar nära samarbete mellan olika sektorer för att länderna på bästa vis ska utveckla effektiva lösningar.

Två exempel från initiativets delprojekt:

\section{Integrering av utsatta grupper på} arbetsmarknaden är ett av initiativets fokusområden. Detta delprojekt ska bidra till ökad inkludering av samhällets svaga på den nordiska arbetsmarknaden. Målgruppen är ungdomar i övergången från utbildning till arbete, personer med psykisk och fysisk sjukdom samt äldre personer. Ett annat fokusområde är rekrytering av utländsk arbetskraft samt invandrares arbetsmiljö och anknytning till den nordiska arbetsmarknaden. Detta projekt ska bidra till att öka närvaron av kvalificerad utländsk arbetskraft $i$ Norden för att på så vis bredda arbetskraften med de kompetenser som det är störst efterfrågan på i länderna.

www.norden.org/sv/ nordiska-ministerraadet/ globaliseringssamarbetet/ konkreta-globaliseringsinitiativ/ globaliseringsinitiativetindenfor-velfaerd-og-sundhed 


\section{Gemensamma insatser mot människohandel}

Varje år sker olaglig handel över landsgränserna med kvinnor, män och barn. Människohandel är ett komplext problem som är nära relaterat till de generella globaliserings- och utvecklingstendenserna i världen.

För att kunna stoppa handeln med människor finns det ett behov av gemensamma kunskaper och förståelse av de nya former av organiserat, kriminellt utnyttjande av människor som förekommer idag. Regionalt och internationellt samarbete mellan både myndigheter och NGO:er är nödvändigt för att lösa problemen. Det nordiska samarbetet prioriterar insatser mot människohandel högt och arbetar för att stärka det regionala samarbetet med nordvästra Ryssland, Estland, Lettland och Litauen.
De nordiska samarbetsministrarna antog i februari 2011 ett program för att bekämpa människohandel. Programmet består av fem delprojekt och fokuserar på sociala aspekter av människohandel. För att förstärka den regionala plattformen för samarbete mellan Norden och grannländer inom regionen för den nordliga dimensionen fäster man stor vikt vid erfarenhetsutbyte och kunskapsdelning över nationsgränserna. Programmet har bland annat fokus på nya former av människohandel, inklusive tvångsarbete, tiggeri och barnarbete.

\section{Fri rörlighet skapar välfärd}

Medborgarna i de nordiska länderna ska enkelt kunna röra sig inom regionen. Arbetet med att identifiera och avlägsna hinder för denna fria rörlighet, så kallade gränshinder, är därför en central uppgift för Nordiska ministerrådet. Gränshinderarbetet ingår i en överordnad strategi för att få en välfungerande inre marknad i Norden, såväl för privatpersoner som för företag. Möjligheten att i så hög grad som möjligt kunna utnyttja varandras arbetsmarknader, liksom att kunna bedriva näringsverksamhet över gränserna, stärker ländernas ekonomiska bas och därmed välfärdssamhällen.

I juni 2007 fattade de nordiska statsministrarna beslut om att "med alla medel undanröja de svårigheter som medborgarna kan stöta på i det nordiska umgänget”. Detta beslut konkretiserades året efter genom upprättandet av en särskilt tillsatt grupp, Gränshinderforum.

Gränshinderforum arbetar med att identifiera och utarbeta lösningsförslag till konkreta gränshinder och initierar också nordiskt samarbete kring implementering av 
EU-direktiv. Man har även samråd i samband med utarbetandet av nationella lagar. Rutinerna ska motverka att länderna inför nya lagar och regler som försvårar eller begränsar mobiliteten inom Norden.

På senare år har insatser gjorts för att lösa ett flertal konkreta gräns- hinder, såväl på skatteområdet och socialförsäkringsområdet som närings- och arbetsmarknadsområdet. Varje år har 5-10 konkreta hinder kunnat lösas. En aktuell fråga som man har arbetat med under en längre tid och som det nu förhandlas om inom EU är frågan om socialförsäkringstillhörighet för personer som bor i ett land men arbetar i två länder samtidigt.

De nordiska länderna har också en gemensam informationstjänst, hallo Norden, som ger vägledning till framför allt privatpersoner som rör sig mellan länderna i Norden.

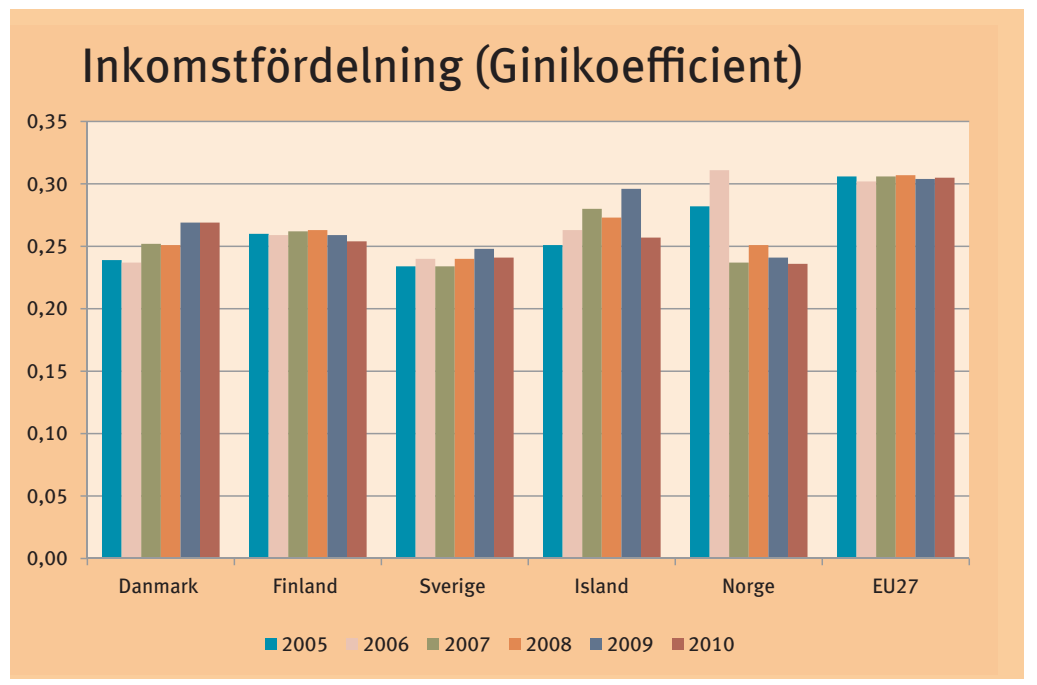




\section{En hållbar utveckling kräver kunskap och deltagande}

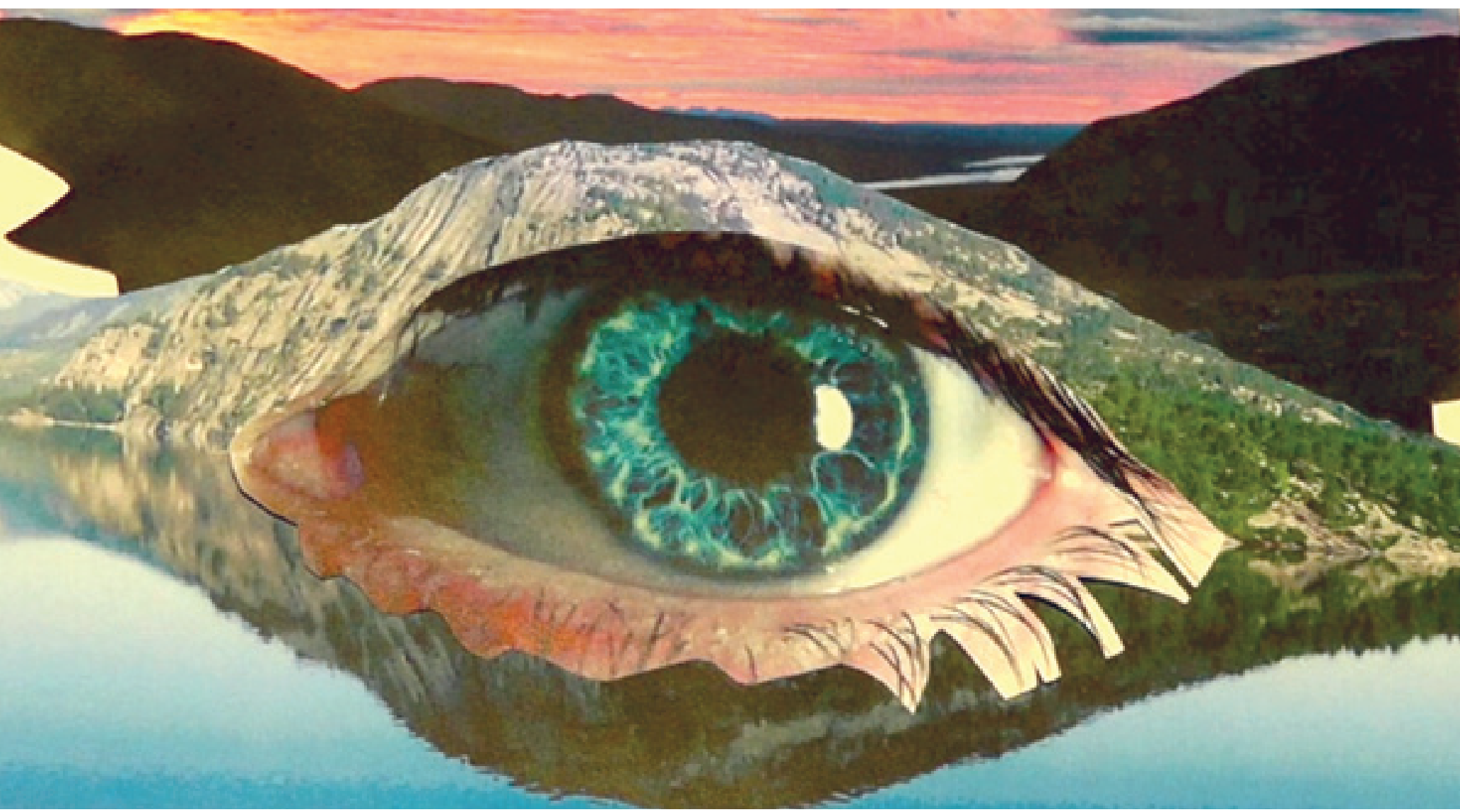


För att kunna skapa en hållbar utveckling är det viktigt att alla har en möjlighet att bidra till förändringsarbetet. Utbildning och kunskap kring hållbar utveckling är en av förutsättningarna för att den enskilda medborgaren ska kunna ta aktiv del i förändringen. De nordiska länderna arbetar därför för att integrera hållbar utveckling i både grundskoleutbildning och annan utbildning.

De nordiska länderna är föregångare i arbetet med lokala strategier för hållbar utveckling, exempelvis inom ramarna för lokal Agenda 21. Nordiska ministerrådet arbetar för att stärka detta arbete ytterligare, till exempel genom att främja erfarenhetsutbyte mellan kommuner i regionen. Befolkningens möjlighet att delta och påverka hållbarhetsarbetet på lokal nivå är en förutsättning för omställningen till ett mer hållbart samhälle. De nordiska länderna verkar därför för att främja allmänhetens möjligheter att engagera sig och utöva inflytande i beslutsprocesser.
För att vi ska kunna ställa om våra samhällen till mer hållbara sådana är det också nödvändigt att våra forsknings- och innovationsmiljöer rustas för att möta behoven av nya lösningar och kunskap. De nordiska utbildnings-, forsknings-, och innovationsinsatserna utformas därför för att bidra till produktion av kunskap och teknik som stödjer en hållbar utveckling.

\section{Norden satsar på forskning om klimat och energi}

Toppforskningsinitiativet är den största gemensamma nordiska forskningssatsning som någonsin lanserats. Initiativet är ett nordiskt flaggskeppsprojekt när det gäller regionalt samarbete omkring forskning och innovation. Initiativet fokuserar på klimat och energi med målet att ge ett nordiskt bidrag till lösningarna på den globala klimatkrisen. Initiativet ska samtidigt stärka Norden som forsknings- och innovationsregion. Satsningen inriktas på de områden inom klimat- och energiforskningen där de nordiska länderna har gemen- samma intressen och där Norden kan bidra till lösningar internationellt. Förankringen i ländernas nationella satsningar är också central.

Toppforskningsinitiativet samlar deltagare från samtliga nordiska länder. Två tredjedelar av projektdeltagarna kommer från universitets- och forskningsvärlden, knappt en tredjedel från näringslivet och en knapp en tiondedell av deltagarna kommer från annat håll. Denna sammansättning av deltagare syftar till att stärka samarbetet mellan ledande forskningsmiljöer och industrin.

Toppforskningsinitiativet är ett unikt projekt där länderna i tillägg till "seed money" från Nordiska ministerrådet kompletterar med nationella medel och därmed skapar en kritisk massa omkring projektet. Projektet förstärker det internationella forskningsnätverket på ett betydande sätt.

www.toppforskningsinitiativet.org/ 


\section{Nordiska klimatdagen}

Under 2011 arrangerades Nordiska klimatdagen för tredje gången. Målet med Nordiska klimatdagen är att få barn och ungdomar i Norden engagerade i kampen för ett bättre klimat genom att stimulera elevers och lärares engagemang för klimatfrågan. Det är utbildningsministrarna i Norden som bjuder in till Nordiska klimatdagen och målgruppen är elever, lärare, lärlingar och utbildningspersonal i hela Norden.

Som del av Nordiska klimatdagen uppmuntras skolor, kommuner, organisationer etc. till att anordna egna klimataktiviteter i Norden.

2010 anordnade till exempel Lunds universitet tillsammans med Lunds ungdomsforum och Lunds kommun en dialog mellan gymnasieungdomar, forskare, politiker och tjänstemän om hur utsläpp från trafiken i Öresundsregionen kan minskas.

Temat för Nordiska klimatdagen 2011 var mat och klimat. Fokus låg bland annat på klimatvänliga och nordiska produkter, Ny Nordisk Mat och produktion samt transport av livsmedel. Skolor tävlade om att skapa klimatvänliga nordiska snacks. Utdrag från de mest innovativa och tankeväckande bidragen presenteras i en nordisk webbkokbok - en samnordisk webbpublikation med och om klimatvänlig mat från hela Norden.

www.klimanorden.org

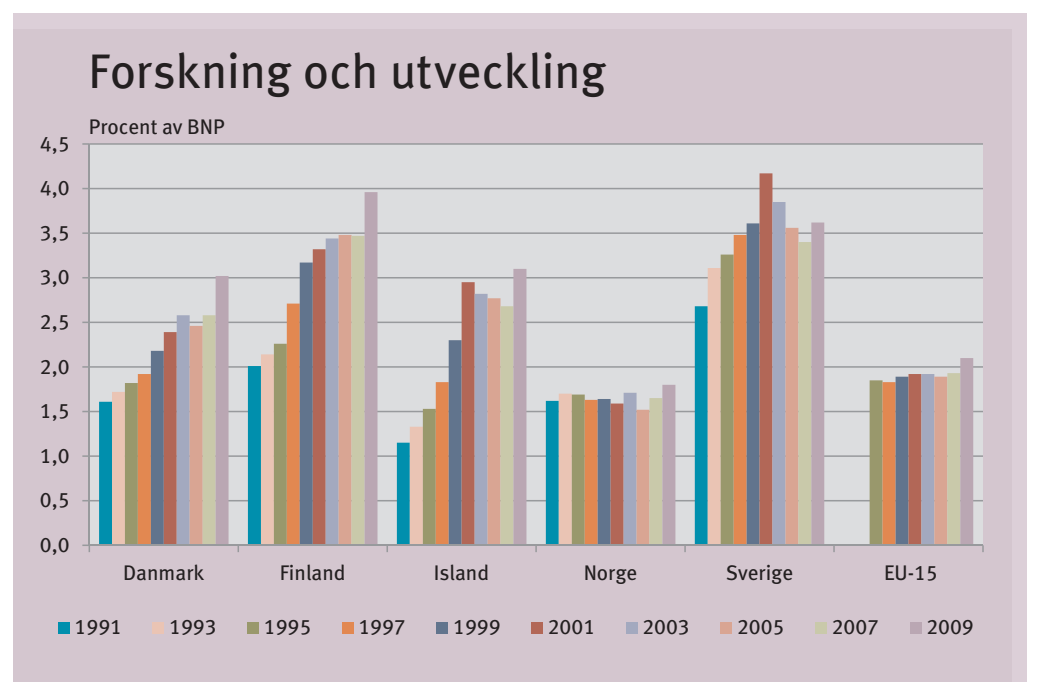




\section{Nordiska masterprogram erbjuder elitstudier i håll- bar utveckling}

Utbildningsprogrammen inom ramarna för Nordic Master

Program samlar det bästa från de nordiska ländernas högre utbildning.

Masterprogrammen kopplar ihop universitetskurser från minst tre nordiska länder till gemensamma utbildningsprogram. Därigenom samlas expertis från universitet i hela Norden vilket gör att dessa program kan erbjuda nordiska och internationella studerande utbildningar av allra högsta kvalitet.

Flera av programmen är specialiserade på studier kring miljö och hållbar utveckling. Bland de universitet som deltagit i Nordic Master Program finner man bland annat de fem tekniska universiteten som utgör Nordic Five Tech.

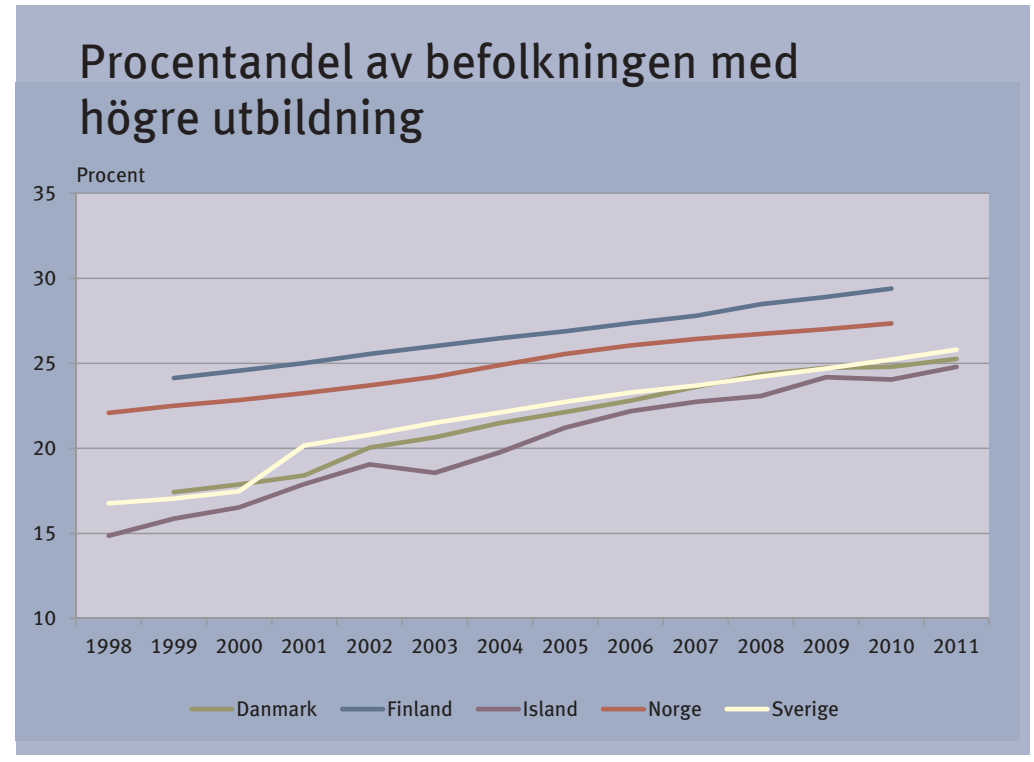

\section{På den nordiska hållbarhets- konferensen utväxlas idéer, erfarenheter och kunskap} Nordiska hållbarhetskonferensen syftar till att stärka global och lokal hållbarhet genom att samla erfarenheter och idéer från den offentliga sektorn, näringslivet, forskare, politiker, icke-statliga organisationer (NGO:er) och medborgare i regionen för att tillsammans identifiera åtgärder för en hållbar utveckling.

Konferenserna hålls med ett par års mellanrum på olika platser i Norden. Den senaste konferensen hölls i Åbo i Finland i början av 
2011. Temat för denna sammankomst var "Lösningar nära, tillsammans". Konferensen fokuserade på vikten av att stärka återkopplingen mellan ekonomiska, sociala och miljömässiga aspekter av hållbar utveckling för att skapa goda lösningar för lokala myndigheter, företag, samhällen och invånare.

Målet med konferensen var att ge deltagarna möjlighet att dela positiva erfarenheter av nya innovationer och tillvägagångssätt samt att erbjuda framför allt kommuner och andra aktörer på lokal nivå genuint användbara och genomförbara idéer.

Planeringen av nästa nordiska konferens har redan startats. Konferensen "Medskapandets konst" ska äga rum i Umeå, Sverige, 2013.

www.solutions2011.fi www.medskapande2013.se

\section{Landskapsarkitektur som betonar hållbarhet}

Biologisk mångfald i ett urbant sammanhang, interaktion mellan infrastruktur och landskap, processinriktad stadsplanering, en närmare titt på Islands användning av geotermisk energi och utnyttjandet av rester från den norska oljeindustrin.

Detta var teman för de nordiska ländernas gemensamma utställning "New Nordic Landscapes" som visades på världsutställningen i Shanghai under 2010. Utställningen satte fokus på landskapsarkitekturens strategiska roll i hållbar utveckling och visade att landskapsarkitektur kan handla om så mycket mer än bara vackra ting. God landskapsarkitektur kan bidra till hållbara lösningar, främja hälsa och skapa bättre levnadsförhållanden för människor i både städer och landsbygdsregioner.
Utställningen satte fokus på att det är viktigt att finna nya och alternativa planeringsmetoder och strategier som betonar medveten användning av naturresurser och kombinerar det senaste inom teknologi och globalt kunnande med en medvetenhet om lokala förhållanden, kultur och identitet. Ett nära förhållande till naturen och strävan efter en balans mellan utnyttjande, utvecklande och skydd av naturresurser och landskap är traditionellt viktiga ingredienser i den nordiska kulturhistorien. Denna typ av hänsynstaganden har blivit ännu viktigare i ljuset av dagens miljöutmaningar. 


\section{Finlands arbete med hållbar utveckling}

Arbetet för en hållbar utveckling i Finland har pågått sedan 1980-talet. Finlands kommission för hållbar utveckling, en av de första i världen, inrättades år 1993. Den finländska kommissionen räknas som unik eftersom den bygger på en öppen dialog mellan regering, förvaltning, näringsliv och medborgarsamhälle. Kommissionen har flera gånger lyft fram viktiga teman i den nationella dialogen, påverkat innehållet i regeringsprogrammen och varit med om att skapa politiskt samförstånd i frågor som rör hållbar utveckling.

Arbetet inom Finlands kommission för hållbar utveckling bygger på den nationella strategin "På väg mot hållbara val. Ett nationellt och globalt hållbart Finland" från juni 2006. I strategin sammankopplas hållbart utnyttjande och skydd av naturresurser samt medborgarnas välbefinnande och social sammanhållning. På grund av strategins mål och förslag har aktörer i både den offentliga och den privata sektorn samt i medborgarsamhället utarbetat sina egna program och strategier. Till exempel har ett tvärsektoriellt handlingsprogram för hållbar konsumtion och produktion (HKP) genomförts, redogörelser för klimat- och energipolitiken samt en smart och ansvarsfull naturresursekonomi utarbetats, en strategi för ett socialt hållbart samhälle 2020 godkänts och flera miljöhandlingssystem tagits i bruk.

Finlands hållbarhetspolitik har också gett upphov till konkreta initiativ som införts. Exempelvis har man som en följd av HKP-programmet etablerat en materialeffektivitetscentral och främjat offentlig hållbar upphandling genom regeringens principbeslut.

Trots alla statliga insatser uppkommer de modigaste och mest innovativa lösningarna ofta på lokal nivå. Ett bra exempel är det så kalllade Hinku-projektet där fem finska kommuner åtog sig att bli pionjärer i snabbare minskning av växthusgasutsläpp än vad EU-ställda mål och den överenskomna tidtabellen förutsätter. Inom loppet av två år har dessa kommuner genomfört över 70 åtgärder för att främja energieffektivitet, energibesparing, användning av förnybara naturresurser och miljömässiga investeringar. Projektet har understrukit att med hjälp av den moderna teknologin kan ambitiösa klimatmål genom positiv medverkan uppnås även i kommunernas miljö, sysselsättning och ekonomiska aktivitet. 


\section{För mer information, se följande resurser:}

Webbsida om det nordiska samarbetet om hållbar utveckling www.norden.org/sv/nordiska-ministerraadet/ samarbetsministrarna-mr-sam/haallbar-utveckling

Nordiska indikatorer för hållbar utveckling www.norden.org/sv/nordiska-ministerraadet/ samarbetsministrarna-mr-sam/haallbar-utveckling/ indikatorer-foer-haallbar-utveckling

Publikationer från Nordiska ministerrådet www.norden.org/sv/publikationer

Nyhetsbrevet NordMiljö

www.norden.org/sv/nordmiljoe

Facebooksida om det nordiska samarbetet om hållbar utveckling www.facebook.com/sdnordic

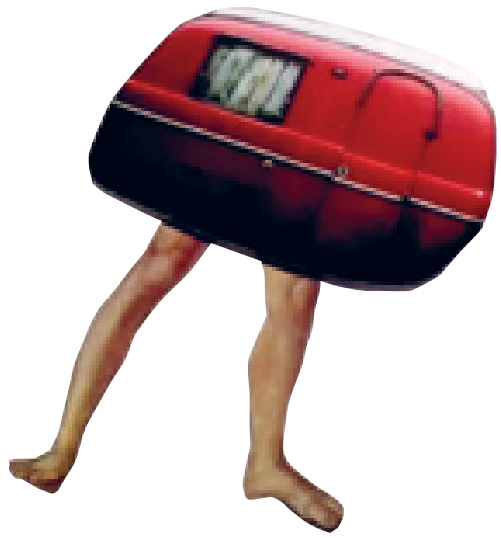




\section{Nordiska ministerrådet}

Det nordiska samarbetet omfattar Danmark, Finland, Island, Norge och Sverige samt de tre självstyrande områdena Färöarna, Grönland och Åland. Det formaliserade samarbetet mellan de nordiska länderna är ett av de äldsta och mest omfattande regionala samarbetena i världen. Samarbetet bygger på gemensamma värderingar och en vilja att uppnå resultat som bidrar till en dynamisk utveckling och som ökar Nordens kompetens och konkurrenskraft.

Nordiska ministerrådet grundades år 1971 och är de nordiska regeringarnas officiella samarbetsorgan. De nordiska statsministrarna och de politiska ledarna för de självstyrande områdena har det yttersta ansvaret för samarbetet inom Nordiska ministerrådet. Regeringssamarbetet ska arbeta för gemensamma nordiska lösningar som ger påtagliga positiva effekter, nordisk nytta, för medborgarna i de enskilda nordiska länderna och i de tre självstyrande områdena.

Utgångspunkten för det nordiska samarbetet är ett fokus på områden där gemensamma nordiska insatser skapar mervärde för de enskilda nordiska länderna och deras medborgare. Samarbetet omfattar bland annat näringslivspolitik, ekonomiska och juridiska frågor, social- och hälsopolitik samt jämställdhet, arbetsliv och jord- och skogsbruk. Andra viktiga frågor i det nordiska samarbetet kretsar kring klimat, miljö och energi, forskning, utbildning och innovation samt förbättrad regional integration genom undanröjande av gränshinder mellan länderna.

Resultaten av de nordiska ländernas gemensamma ansträngningar kan ses i medborgarnas vardag. Samarbetet har bland annat resulterat $\mathrm{i}$ en gemensam nordisk arbetsmarknad, en passunion och en rad gemensamma sociala bestämmelser. De nordiska medborgarna har också länge kunnat bosätta sig och studera överallt i Norden.

www.norden.org 


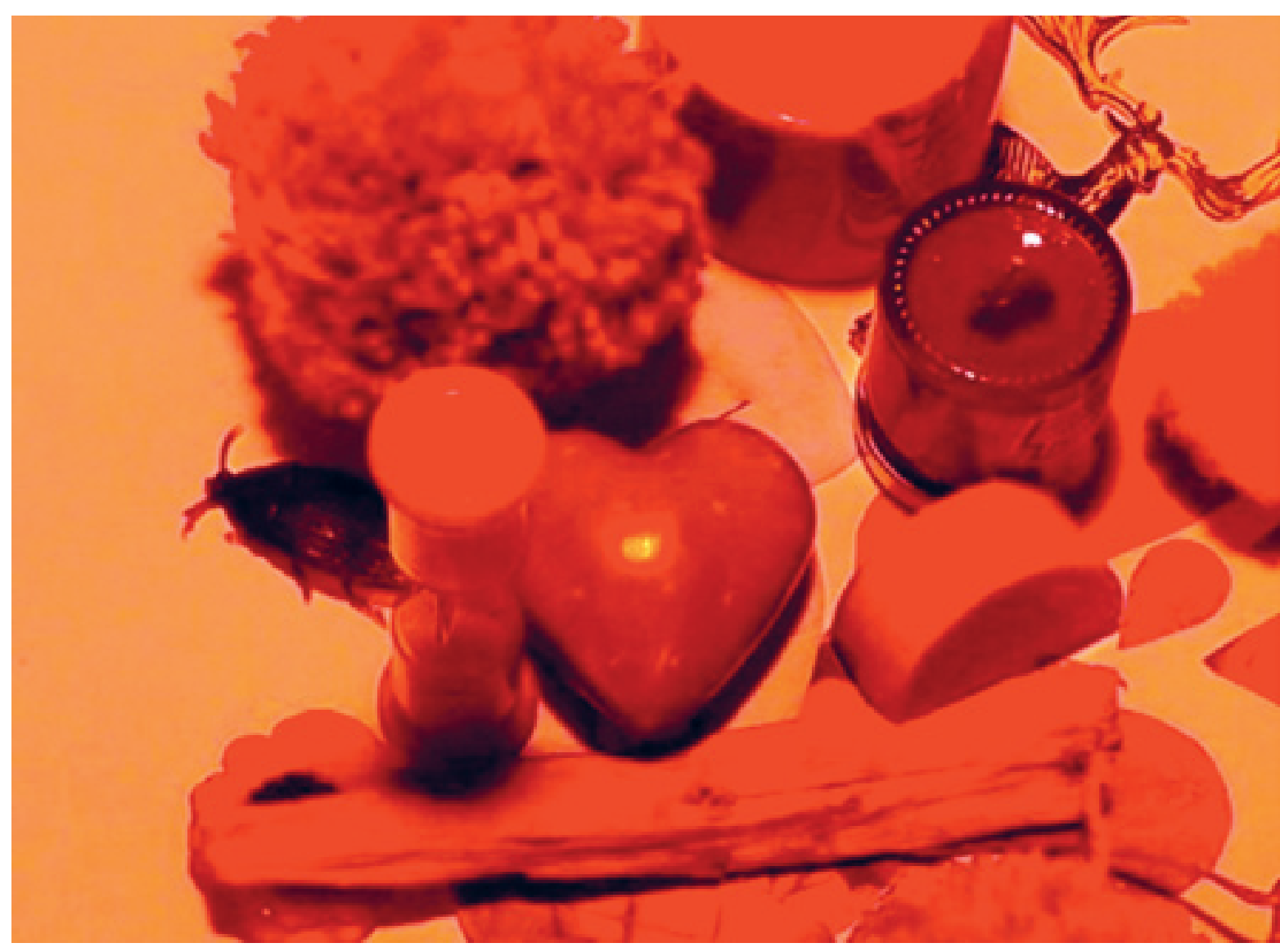




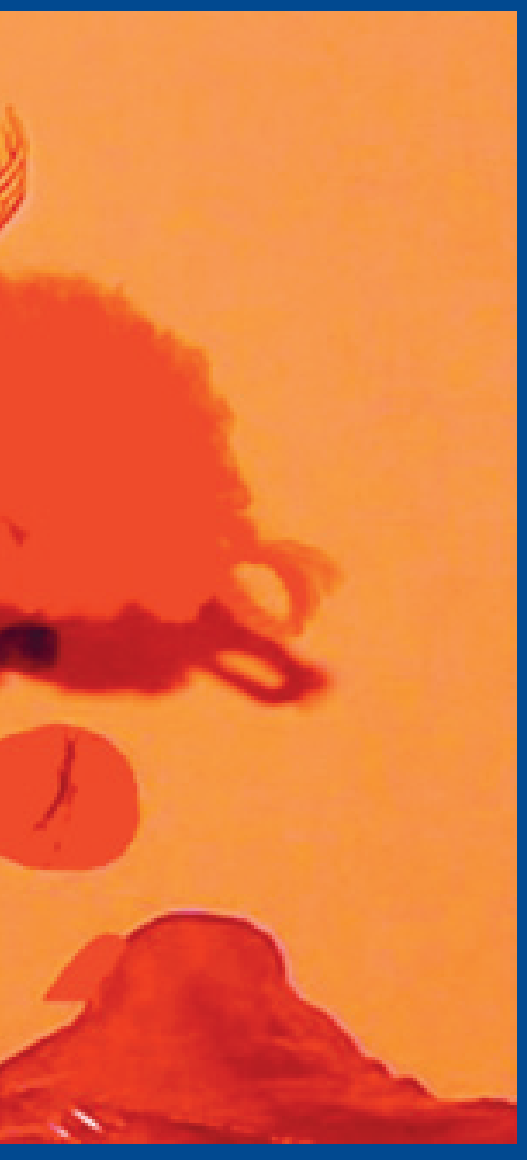




\section{norden}

Nordiska ministerrådet

Ved Stranden 18

DK-1061 København K

www.norden.org

\section{Donera ett ord}

Vad är hållbarhet för dig? Vad innebär det att vara mänsklig? Och vad förknippar du med ordet natur?

Vi samlar in ord från hela världen för att skapa ett globalt collage över tankar och idéer om hållbar utveckling.

\section{Var med på}

www.norden.org/donateaword

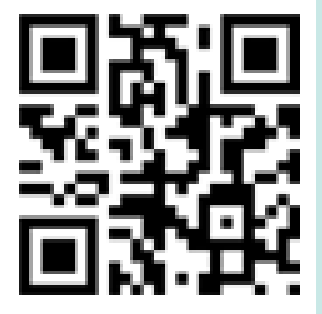

ISBN: 978-92-893-2360-4

ANP 2012:732 